\title{
Pengaruh Motivasi dan Perilaku Belajar Terhadap Prestasi Akademik Mahasiswa
}

\author{
Tarida Marlin Surya Manurung ${ }^{1}$
}

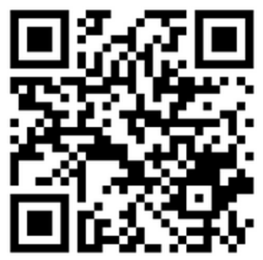

\begin{abstract}
Abstrak
Prestasi akademik merupakan sebuah istilah untuk menunjukkan suatu pencapaian atau tingkat keberhasilan tentang suatu tujuan sebagai hasil dari usaha belajar yang telah dilakukan oleh seseorang secara optimal. Prestasi akademik menjadi salah satu tolak ukur keberhasilan mahasiswa dalam menyelesaikan studinya di bangku kuliah. Pencapaian prestasi akademik mahasiswa dapat dipengaruhi oleh faktor internal dan eksternal setiap individu.Tujuan Penelitian ini adalah untuk mengetahui dan menganalisis : (1) Pengaruh Motivasi Belajar Terhadap Prestasi Akademik Mahasiswa, (2) Pengaruh Motivasi Belajar Terhadap Perilaku Belajar Mahasiswa dan (3) Pengaruh Perilaku Belajar Terhadap Prestasi Akademik Mahasiswa. Penelitian dilakukan di STIE Kesatuan Bogor dengan 150 orang mahasiswa sebagai responden dari lima program studi. Data diolah dan dianalisis menggunakan structural equation model dengan SmartPLS 2.0M. Hasil Penelitian menunjukkan bahwa a. Motivasi Belajar berpengaruh positif dan signifikan terhadap Prestasi Akademik, b. Motivasi Belajar berpengaruh positif dan signifikan terhadap Perilaku Belajar dan c. Perilaku Belajar berpengaruh positif dan signifikan terhadap Prestasi Akademik Mahasiswa. Diperlukan pengembangan model lebih lanjut agar dapat memberi gambaran yang lebih utuh dan komprehensif tentang faktor-faktor yang mempengaruhi meningkatnya Prestasi Akademik para Mahasiswa.
\end{abstract}

Kata Kunci: motivasi belajar, perilaku belajar, prestasi akademik, mahasiswa

\section{Abstract}

An academic achievement is a term used to identify an achievement or level of success about a goal as a result of a learning effort that has been done optimally by someone. An academic achievement became one of the benchmarks of a student's success in completing his studies in college. Internal and external factors of individuals can influence the students' academic achievement. The purpose of this research is to identify and analyze (1) Influence of Learning Motivation to Academic Achievement of Student, (2) Influence of Learning Motivation to Student Learning Behavior and (3) Influence of Learning Behavior to Student Achievement. The research was conducted at STIE Kesatuan Bogor with 150 students as respondents from five study programs. The data were processed and analyzed using structural equation model with Smart PLS 2.0M. The results showed that a. Learning Motivation has positive and significant impact on Academic Achievement, $b$. Learning Motivation has a positive and significant impact on Learning Behavior and c. Learning Behavior has a positive and significant impact on Student Achievement. Further modeling is needed in order to provide a more complete and comprehensive picture of the factors that influence the increase of Academic Achievement of the Students.

Keywords: learning motivation, learning behavior, academic achievement, student

\section{Pendahuluan}

Mahasiswa merupakan insan akademis yang memiliki bagian dan peranan sangat penting pada sebuah lembaga pendidikan tinggi. Penyelenggaraan pendidikan diupayakan secara optimal memenuhi bahkan melebihi standar mutu yang telah ditetapkan oleh pemerintah. Proses pembelajaran tidak hanya berfokus pada pendidikan yang bersifat hard skills namun juga soft skills. Hal ini agar para mahasiswa memiliki
1. Program Studi Manajemen, STIE Kesatuan, Jl. Ranggagading No. 1 Bogor, 16123, Indonesia

EMail

marlin1408@gmail.com

\section{Submitted : Juni 2017 Accepted : Juli 2017}


bekal yang memadai untuk dapat memenangkan persaingan perolehan pekerjaan dan memiliki profesi yang gemilang.

Sekolah Tinggi IImu Ekonomi (STIE) Kesatuan merupakan sebuah perguruan tinggi swasta yang berlokasi di wilayah Kota Bogor, dengan visi utamanya adalah Menjadikan STIE Kesatuan sebagai Perguruan Tinggi terbaik di Bogor tahun 2020, yang mengutamakan profesionalisme, kualitas, serta selalu bertumbuh dan berkembang.Terdapat beberapa program studi yang terdapat pada STIE Kesatuan, yakni: S1 Akuntansi, S1 Manajemen, D3 Akuntansi, D3 Pemasaran, dan D3 Keuangan Perbankan.

Penyelenggaraan seluruh program studi tersebut senantiasa mengedepankan profesionalisme dan kualitas secara optimal, sehingga diharapkan seluruh mahasiswa memiliki kompetensi yang handal sesuai dengan bidang ilmu yang dipelajari. Prestasi akademik merupakan sebuah istilah untuk menunjukkan suatu pencapaian atau tingkat keberhasilan tentang suatu tujuan sebagai hasil dari usaha belajar yang telah dilakukan oleh seseorang secara optimal. Prestasi akademik menjadi salah satu tolak ukur keberhasilan mahasiswa dalam menyelesaikan studinya di bangku kuliah.

Pencapaian prestasi akademik mahasiswa dapat dipengaruhi oleh faktor internal dan eksternal setiap individu. sejumlah alasan akan menimbulkan motivasi dalam diri individu untuk mengatur dirinya sendiri. Robbins dan Judge (2008) menjelaskan bahwa motivasi merupakan proses yang menjelaskan intensitas, arah dan ketekunan usaha untuk mencapai suatu tujuan. Motivasi merupakan dorongan atau penggerak dasar bagi suatu keinginan, harapan dan tujuan yang dimiliki individu. Motivasi dapat bersumber dari dalam diri sendiri tanpa adanya paksaan dari orang lain dan motivasi dapat bersumber dari dorongan atau rangsangan dari orang lain. Apabila seseorang termotivasi untuk melakukan suatu kegiatan seperti belajar, maka dorongan tersebut akan mempengaruhi proses yang mengarah kepada tujuan yang ingin dicapai. Sebaliknya, apabila seseorang tidak termotivasi untuk melakukan suatu kegiatan, maka hal tersebut juga mempengaruhi usaha ataupun proses pencapaian tujuan.

Meskipun IPK bukan merupakan jaminan kualitas mutlak, namun IPK yang diperoleh mahasiswa selama kuliah biasanya menjadi acuan dalam mengukur prestasi mahasiswa. Hal ini dikarenakan IPK merupakan rata-rata nilai kumulatif yang diperoleh mahasiswa dan atau lulusan suatu program studi. Dengan kata lain, keberhasilan studi sering disamakan dengan nilai IPK yang tinggi. Mengacu pada pemaparan latar belakang tersebut di atas maka diperlukan suatu kajian komprehensif dengan judul "Pengaruh Motivasi dan Perilaku Belajar Terhadap Prestasi Akademik Mahasiswa (Studi Kasus pada Mahasiswa STIE Kesatuan Bogor).

Identifikasi dan perumusan masalah yang akan dibahas lebih lanjut dalam penelitian ini adalah sebagai berikut: (1) Bagaimana Pengaruh Motivasi Belajar Terhadap Prestasi Akademik Mahasiswa STIE Kesatuan Bogor? (2) Bagaimana Pengaruh Motivasi Belajar Terhadap Perilaku Belajar Mahasiswa STIE Kesatuan Bogor? (3) Bagaimana Pengaruh Perilaku Belajar Terhadap Prestasi Akademik Mahasiswa STIE Kesatuan Bogor?

Merujuk pada identifikasi masalah tersebut, Penelitian ini memiliki tujuan untuk mengetahui dan menganalisis: (1) Pengaruh Motivasi Belajar Terhadap Prestasi Akademik Mahasiswa STIE Kesatuan Bogor (2) Pengaruh Motivasi Belajar Terhadap Perilaku Belajar Mahasiswa STIE Kesatuan Bogor (3) Pengaruh Perilaku Belajar Terhadap Prestasi Akademik Mahasiswa STIE Kesatuan Bogor

\section{Metode Penelitian}

Penelitian ini dilaksanakan pada bulan Januari - Maret 2017 di Sekolah Tinggi IImu Ekonomi Kesatuan dengan menjadikan 100 (seratus) orang Mahasiswa sebagai responden dengan sebaran merata Metode penelitian yang digunakan pada penelitian ini adalah metode penelitian survey. Metode ini merupakan sebuah cara yang ilmiah untuk memperoleh data dengan tujuan dan kegunaan tertentu. Cara ilmiah merupakan kegiatan penelitian ini didasarkan pada ciri-ciri khas keilmuan, seperti rasional, empiris dan sistematis. Selain itu, penggunaan metode ini juga dikarenakan data diperoleh dari sampel yang kemudian akan digeneralisir ke dalam populasi.

Jenis data pada penelitian ini adalah data primer dan data sekunder. Sumber data penelitian ini terkait variabel Motivasi dan Perilaku Belajar Mahasiswa adalah dari jawaban-jawaban yang diberikan oleh responden penelitian, pada instrumen kuesioner yang telah disediakan peneliti. Instrumen penelitian disusun dengan tipe pertanyaan tertutup dan tipe pertanyaan terbuka. Sedangkan data Prestasi Akademik yang digambarkan dengan Indeks Prestasi Kumulatif (IPK) merupakan data sekunder yang diperoleh dari Biro Administrasi Akademik dan Kemahasiswaan STIE Kesatuan Bogor. 
Populasi penelitian ini adalah seluruh mahasiswa STIE Kesatuan yang terdaftar, aktif mengikuti perkuliahan dan telah memiliki nilai indeks prestasi. Sampel dipilih dengan menggunakan teknik stratified random sampling, yakni dengan memperhatikan program studi, dan tingkat semester mahasiswa. Ukuran sampel ditarik dengan menggunakan teknik Slovin, dengan kesalahan penarikan sampel yang ditoleransi sebesar 5\%.

Operasionalisasi variabel-variabel yang digunakan dalam penelitian ini adalah sebagai berikut: (a) Prestasi Akademik, didefinisikan sebagai pencapaian hasil belajar mahasiswa pada kampus STIE Kesatuan, diukur melalui pencapaian nilai indeks prestasi mahasiswa secara kumulatif. (b) Motivasi Belajar didefinisikan sebagai Proses yang menjelaskan intensitas, arah dan ketekunan usaha untuk mencapai suatu tujuan (Robbins dan Judge, 2008). Indikator variabel ini terdiri dari Proses perkuliahan yang menyenangkan, Adanya target yang ingin dicapai, Kuliah sangat penting untuk bekal di masa depan, Adanya penghargaan yang sesuai dan Adanya persaingan. (c) Perilaku Belajar didefinisikan sebagai Seluruh kegiatan atau aktivitas manusia, baik yang dapat diamati langsung maupun yang tidak dapat diamati pihak luar (Januar, 2013) dengan indikator Perilaku mengikuti perkuliahan, Perilaku membaca buku, Perilaku mengunjungi perpustakaan, Perilaku saat menghadapi ujian dan Perilaku belajar di rumah atau kos

Pengumpulan data primer dilakukan dengan menggunakan bantuan instrumen kuesioner atau angket yang disusun dengan kombinasi antara tipe pertanyaan tertutup dan tipe pertanyaan terbuka. Pada tipe pertanyaan tertutup, disusun lima alternatif jawaban pada pertanyaan inti dengan menggunakan skala Likert. Metode analisis data penelitian ini adalah sebagai berikut:

1. Analisis Deskriptif. Analisis ini dilakukan dengan pengumpulan dan penyajian data sehingga lebih mudah dipahami. Analisis ini menerangkan keadaan, gejala maupun persoalan. Analisis deskriptif ini menggunakan data pada suatu kelompok untuk menjelaskan maupun menarik kesimpulan mengenai kelompok tersebut saja. Teknik ini digunakan untuk menganalisis data dengan cara mendeskripsikan atau menggambarkan data yang telah terkumpul sebagaimana adanya tanpa bermaksud membuat kesimpulan yang berlaku untuk umum atau generalisasi.

2. Analisis Inferensial. Untuk menguji hipotesis dan menghasilkan suatu model yang layak (fit), penelitian ini menggunakan Structural Equation Modeling (SEM) dengan pendekatan variance based atau component based dengan Partial Least Square (PLS). Di dalam PLS model struktural hubungan antar variabel laten disebut dengan inner model, sedangkan model pengukuran (bersifat refleksif atau formatif) disebut outer model. Disisi lain, di dalam SEM tidak dibedakan dengan tegas antar keduanya, namun demikian terdapat istilah overall model untuk model keseluruhan, yaitu gabungan antara model struktural hubungan antar variabel laten dan model pengukuran dengan CFA (confirmatory factor analisys).

Langkah-langkah dalam analisis PLS adalah sebagai berikut: (a) Pengembangan model berbasis teori atau inner model. Pengembangan model berbasis konsep dan teori dalam rangka menganalisis hubungan antara variabel eksogen dan endogen telah dijabarkan dalam kerangka konseptual. (b) Pengembangan diagram alur (Path Diagram). Model teoritis yang telah dibangun dalam kerangka konseptual kemudian digambar dalam sebuah diagram alur yang berfungsi untuk menunjukkan hubungan antara variabel eksogen dan endogen.

\section{Hasil Penelitian Dan Pembahasan}

Karakteristik Responden

Jumlah responden yang menjadi sampel dalam penelitian ini berjumlah 150 orang mahasiswa yang berasal dari 5 (lima) Program Studi di Sekolah Tinggi Ilmu Ekonomi Kesatuan.

Tabel 1. Sebaran Sampel Berdasarkan Karakteristik Responden

\begin{tabular}{cccc}
\hline & Karakteristik Responden & Frekuensi & $\%$ \\
\hline \multirow{2}{*}{ Jenis Kelamin } & Laki-laki & 79 & 52.67 \\
& Wanita & 71 & 47.33 \\
\multirow{3}{*}{ Semester } & Total & 150 & 100.00 \\
& 3 (Tiga) & 53 & 35.33 \\
& 5 (Lima) & 53 & 35.33 \\
& 7 (Tujuh) & 44 & 29.33 \\
& Total & 150 & 100.00
\end{tabular}




\begin{tabular}{|c|c|c|c|c|c|}
\hline \multicolumn{3}{|c|}{ Karakteristik Responden } & & Frekuensi & $\%$ \\
\hline \multicolumn{2}{|c|}{ Program Studi } & \multicolumn{2}{|l|}{ Akuntansi S1 } & 35 & 23.33 \\
\hline & & \multicolumn{2}{|l|}{ Manajemen S1 } & 52 & 34.67 \\
\hline & & \multicolumn{2}{|l|}{ Akuntansi D3 } & 14 & 9.33 \\
\hline & & \multicolumn{2}{|c|}{ Keuangan dan Perbankan D3 } & 24 & 16.00 \\
\hline & & \multicolumn{2}{|c|}{ Manajemen Pemasaran D3 } & 25 & 16.67 \\
\hline & & \multicolumn{2}{|l|}{ Total } & 150 & 100.00 \\
\hline \multirow{6}{*}{\multicolumn{2}{|c|}{ Indeks Prestasi Kumulatif }} & \multicolumn{2}{|l|}{$1.50-1.99$} & 0 & 0.00 \\
\hline & & \multicolumn{2}{|l|}{$2.00-2.49$} & 14 & 9.33 \\
\hline & & \multicolumn{2}{|l|}{$2.50-2.99$} & 55 & 36.67 \\
\hline & & \multicolumn{2}{|l|}{$3.00-3.49$} & 53 & 35.33 \\
\hline & & \multicolumn{2}{|l|}{$3.50-4.00$} & 28 & 18.67 \\
\hline & & \multicolumn{2}{|l|}{ Total } & 150 & 100.00 \\
\hline \multicolumn{6}{|c|}{ Sumber: Data Primer Diolah, 2017} \\
\hline \multicolumn{6}{|c|}{ Deskripsi Variabel Penelitian } \\
\hline \multicolumn{6}{|c|}{ Tabel 2 Distribusi Frekuensi Persepsi Responden atas Indikator - Indikator Motivasi Belajar } \\
\hline NO & INDIKATOR & JAWABAN & FREKUENSI & SKOR & INTERPRETASI \\
\hline \multirow{6}{*}{1} & \multirow{6}{*}{$\begin{array}{l}\text { Target Yang Ingin } \\
\text { dicapai }\end{array}$} & Sangat tidak setuju & 0 & & \\
\hline & & Tidak setuju & 0 & & \\
\hline & & Netral & 19 & 95.2 & Sangat Kuat \\
\hline & & Setuju & 40 & & \\
\hline & & Sangat setuju & 41 & & \\
\hline & & Sangat tidak setuju & 0 & & \\
\hline \multirow{4}{*}{2} & Kuliah Sangat Penting & Tidak setuju & 0 & & \\
\hline & Untuk Bekal Masa & Netral & 5 & 92.27 & Sangat Kuat \\
\hline & Depan & Setuju & 48 & & \\
\hline & & Sangat setuju & 97 & & \\
\hline \multirow{5}{*}{3} & \multirow{5}{*}{$\begin{array}{l}\text { Adanya Penghargaan } \\
\text { Yang Sesuai }\end{array}$} & Sangat tidak setuju & 0 & & \\
\hline & & Tidak setuju & 2 & & \\
\hline & & Netral & 2 & 89.33 & Sangat Kuat \\
\hline & & Setuju & 70 & & \\
\hline & & Sangat setuju & 76 & & \\
\hline \multirow{5}{*}{4} & \multirow{5}{*}{ Adanya Persaingan } & Sangat tidak setuju & 0 & & \\
\hline & & Tidak setuju & 0 & & \\
\hline & & Netral & 9 & 87.20 & Sangat Kuat \\
\hline & & Setuju & 78 & & \\
\hline & & Sangat setuju & 63 & & \\
\hline & & Sangat tidak setuju & 0 & & \\
\hline & & Tidak setuju & 0 & & \\
\hline 5 & Yang Menvenangkan & Netral & 9 & 85.60 & Sangat Kuat \\
\hline & Yang Menyenangkan & Setuju & 90 & & \\
\hline & & Sangat setuju & 51 & & \\
\hline
\end{tabular}

Sumber : Data primer diolah, 2017

Berdasarkan Tabel 2. dan Tabel 3., dapat dinyatakan bahwa seluruh indikator yang digunakan untuk mengukur variabel laten dipersepsikan Sangat Kuat oleh responden. Responden bersepakat secara bersama bahwa untuk meningkatkan Prestasi Akademik perlu dilakukan peningkatan kesadaran dan pemahasaman Mahasiswa akan target yang ingin dicapai, kuliah sangat penting untuk bekal di masa depan, adanya penghargaan yang sesuai, adanya persaingan, Proses perkuliahan yang menyenangkan, Perilaku belajar di rumah atau kos, Perilaku membaca buku, Perilaku saat menghadapi ujian, Perilaku mengunjungi perpustakaan dan Perilaku mengikuti perkuliahan. 
Tabel 3 Distribusi Frekuensi Persepsi Responden atas Indikator - Indikator Perilaku Belajar

\begin{tabular}{|c|c|c|c|c|c|}
\hline NO & INDIKATOR & JAWABAN & FREKUENSI & SKOR & INTERPRETASI \\
\hline \multirow{5}{*}{1} & \multirow{5}{*}{$\begin{array}{l}\text { Perilaku Belajardi } \\
\text { Rumah/Kos }\end{array}$} & Sangat tidak setuju & 0 & \multirow{5}{*}{94.00} & \multirow{5}{*}{ Sangat Kuat } \\
\hline & & Tidak setuju & 0 & & \\
\hline & & Netral & 4 & & \\
\hline & & Setuju & 37 & & \\
\hline & & Sangat setuju & 109 & & \\
\hline \multirow{5}{*}{2} & \multirow{5}{*}{$\begin{array}{l}\text { Perilaku Membaca } \\
\text { Buku }\end{array}$} & Sangat tidak setuju & 0 & \multirow{5}{*}{86.80} & \multirow{5}{*}{ Sangat Kuat } \\
\hline & & Tidak setuju & 0 & & \\
\hline & & Netral & 12 & & \\
\hline & & Setuju & 75 & & \\
\hline & & Sangat setuju & 63 & & \\
\hline \multirow{5}{*}{3} & \multirow{5}{*}{$\begin{array}{l}\text { Perilaku Menghadapi } \\
\text { Ujian }\end{array}$} & Sangat tidak setuju & 0 & \multirow{5}{*}{91.73} & \multirow{5}{*}{ Sangat Kuat } \\
\hline & & Tidak setuju & 1 & & \\
\hline & & Netral & 1 & & \\
\hline & & Setuju & 57 & & \\
\hline & & Sangat setuju & 91 & & \\
\hline \multirow{5}{*}{4} & \multirow{5}{*}{$\begin{array}{l}\text { Perilaku Mengunjungi } \\
\text { Perpustakaan }\end{array}$} & Sangat tidak setuju & 0 & \multirow{5}{*}{88.00} & \multirow{5}{*}{ Sangat Kuat } \\
\hline & & Tidak setuju & 0 & & \\
\hline & & Netral & 9 & & \\
\hline & & Setuju & 72 & & \\
\hline & & Sangat setuju & 69 & & \\
\hline \multirow{5}{*}{5} & \multirow{5}{*}{$\begin{array}{l}\text { Perilaku Mengikuti } \\
\text { Perkuliahan }\end{array}$} & Sangat tidak setuju & 0 & \multirow{5}{*}{86.40} & \multirow{5}{*}{ Sangat Kuat } \\
\hline & & Tidak setuju & 0 & & \\
\hline & & Netral & 4 & & \\
\hline & & Setuju & 94 & & \\
\hline & & Sangat setuju & 52 & & \\
\hline
\end{tabular}

\section{Evaluasi Fit Model}

Menilai Outer Model dan Measurement Model, Terdapat tiga kriteria di dalam penggunaan teknik analisa data dengan SmartPLS untuk menilai outer model yaitu Convergent Validity, Discriminant Validity, dan Composite Reliability. Convergent Validity dari model pengukuran dengan refleksif indikator dinilai berdasarkan korelasi antara item score atau component score yang diestimasi dengan Soflware PLS. Ukuran refleksif individual dikatakan tinggi jika berkorelasi lebih dari 0.70 dengan variabel yang diukur. Namun menurut Chin (1998) dalam Ghozali (2008) untuk penelitian tahap awal skala pengukuran nilai loading 0.5 sampai 0.6 dianggap cukup memadai. Dalam penelitian ini akan digunakan batas loading factor sebesar 0.5. Hasil pengolahan dengan menggunakan PLS dapat dilihat pada Tabel 4. Nilai outer model atau korelasi antara variabel dengan variabel telah memenuhi convergent validity karena seluruh memiliki nilai loading factor di atas 0.50 .

Tabel 4. $\quad$ Nilai Outer Loadings indikator-indikator dalam Model (Measurement Model)

\begin{tabular}{lccc}
\hline \multirow{2}{*}{ Variabel } & Kode & $\begin{array}{c}\text { Nilai Outer } \\
\text { Loading }\end{array}$ & Keputusan \\
\hline Motivasi Belajar & MB1 & 0.601475 & Tidak dikeluarkan dari Model \\
& MB2 & 0.562266 & Tidak dikeluarkan dari Model \\
& MB3 & 0.602065 & Tidak dikeluarkan dari Model \\
& MB4 & 0.579747 & Tidak dikeluarkan dari Model \\
Perilaku Belajar & MB5 & 0.714640 & Tidak dikeluarkan dari Model \\
& PB1 & 0.591172 & Tidak dikeluarkan dari Model \\
& PB2 & 0.544144 & Tidak dikeluarkan dari Model \\
& PB3 & 0.645272 & Tidak dikeluarkan dari Model \\
& PB4 & 0.531039 & Tidak dikeluarkan dari Model \\
Prestasi Akademik & PB5 & 0.669597 & Tidak dikeluarkan dari Model \\
\hline Sumber: Data Primer Diolah & PAM & 1.000000 & Tidak dikeluarkan dari Model
\end{tabular}

Sumber: Data Primer Diolah

Tabel 4. menunjukan bahwa indikator adanya target yang ingin dicapai (MB1), kuliah sangat penting untuk bekal di masa depan (MB2), adanya penghargaan yang sesuai (MB3), adanya persaingan (MB4) dan Proses perkuliahan yang menyenangkan (MB5), memiliki nilai Outer Loadings lebih dari 0,5. 
Indikator proses perkuliahan yang menyenangkan (MB5) merupakan ukuran terkuat dari variabel motivasi karena memiliki nilai outer loading paling besar (0.715). Sehingga dapat dinyatakan bahwa dari lima indikator motivasi, indikator proses perkuliahan yang menyenangkan merupakan indikator yang paling valid sebagai pengukur variabel prestasi akademik mahasiswa.

Dalam Variabel Perilaku Belajar, kelima indikatornya memiliki outer loading lebih dari 0.5. Perilaku belajar di rumah atau kos (PB1) sebesar 0.591, Perilaku membaca buku (PB2) sebesar 0.544, Perilaku saat menghadapi ujian (PB3) sebesar 0.645, Perilaku mengunjungi perpustakaan (PB4) sebesar 0.531 dan Perilaku mengikuti perkuliahan (PB5) sebesar 0.669. Sehingga dapat dinyatakan bahwa kelima indikator variabel Perilaku Belajar merupakan indikator yang valid sebagai pengukur variabel Prestasi Akademik.

Discriminant validity dilakukan untuk memastikan bahwa setiap konsep dari masing-masing variabel laten berbeda dengan variabel lainnya. Model dikatakan mempunyai discriminant validity yang baik jika setiap nilai loading indikator dari sebuah variabel laten memiliki nilai loading yang lebih besar dibanding nilai loading jika dikorelasikan dengan variabel laten lainnya. Hasil pengujian discriminant validity pada tabel 5.

Dari Tabel 5. dapat dijelaskan bahwa ketiga variabel memiliki nilai AVE di atas 0.50 dan semua variabel memiliki nilai akar AVE lebih tinggi dari koefisien korelasi antar satu variabel dengan variabel lainnya sehingga dapat dikatakan data memiliki discriminant validity yang baik.

Tabel 5 Nilai AVE, Akar AVE dan Korelasi Antar Konstruk Laten

\begin{tabular}{lccccc}
\hline \multicolumn{1}{c}{ Variabel } & MB & $\begin{array}{c}\text { Korelasi } \\
\text { PB }\end{array}$ & PA & AVE & Akar AVE \\
\hline Motivasi Belajar & 1.000000 & & & 0.737443 & 0.858745 \\
Perilaku Belajar & 0.451466 & 1.000000 & & 0.835463 & 0.914037 \\
Prestasi Akademik & 0.757971 & 0.824467 & 1.000000 & 1.000000 & 1.000000 \\
\hline
\end{tabular}

Sumber: Data Primer Diolah

Kriteria validity dan reliabilitas juga dapat dilihat dari nilai reliabilitas suatu variabel dan nilai Average Variance Extracted (AVE) dari masing-masing variabel. Variabel dikatakan memiliki reliabilitas yang tinggi jika nilai composite reliability di atas 0.70 dan AVE berada diatas 0.50 .

Tabel 6 Nilai Composite Reliability Variabel Penelitian

\begin{tabular}{lcc}
\hline & Variabel & Composite Reliability \\
\hline Motivasi Belajar & 0.850530 \\
Perilaku Belajar & 0.834801 \\
Prestasi Akademik & 1.000000 \\
\hline
\end{tabular}

Sumber: Data Primer Diolah

Tabel 6. menunjukkan bahwa seluruh variabel memenuhi composite reliability karena nilainya di atas angka yang direkomendasikan, yaitu diatas 0.7 yang sudah memenuhi kriteria reliable (handal). Berdasarkan dari hasil evaluasi secara keseluruhan, baik convergent. discriminant validity, composite reliability, yang telah dipaparkan di atas, maka dapat disimpulkan bahwa indikator-indikator sebagai pengukur variabel laten merupakan pengukur yang valid dan reliable.

2. Pengujian Model Struktural (Inner Model). Pengujian inner model atau model struktural dilakukan untuk melihat hubungan antara variabel, nilai signifikansi dan $R$-square dari model penelitian. Model struktural dievaluasi dengan menggunakan $R$-square untuk variabel dependen uji t serta signifikansi dari koefisien parameter jalur struktural.

Dari gambar 1 dapat dijelaskan bahwa covariance pengukuran indikator dipengaruhi oleh konstruk laten atau mencerminkan variasi dari konstruk unidimensional yang digambarkan dengan bentuk lingkaran dengan beberapa anak panah dari konstruk ke indikator. Model ini menghipotesiskan bahwa perubahan pada konstruk laten mempengaruhi perubahan pada indikator. Dalam model tersebut terdapat dua variabel eksogen yaitu motivasi dan perilaku belajar dan satu variabel endogen yaitu Prestasi Akademik.

Penilaian model dengan PLS dimulai dengan melihat $R$-square untuk setiap variabel laten dependen. Perubahan nilai $R$-square dapat digunakan untuk menilai pengaruh variabel laten eksogen tertentu terhadap variabel laten endogen yang mempunyai pengaruh substantif.

Gambar 1. menunjukkan nilai $R$-square variabel Perilaku Belajar sebesar 0.204 dan Prestasi Akademik sebesar 0.867 . Semakin tinggi nilai $R$-square, maka semakin besar kemampuan variabel eksogen tersebut dapat menjelaskan variabilitas variabel endogen, sehingga semakin baik persamaan struktural. Untuk variabel Perilaku Belajar memiliki nilai R square sebesar 0.204 yang bermakna bahwa 20.4\% 
variance Perilaku Belajar mampu dijelaskan oleh variabel Motivasi Belajar sedangkan sisanya dijelaskan oleh variabel lain di luar model penelitian. Variabel Prestasi Akademik memiliki nilai $R$-square 0.867 yang bermakna bahwa $86.7 \%$ variance prestasi akademik mampu dijelaskan oleh variabel Motivasi dan Perilaku Belajar secara bersama-sama sedangkan sisanya dijelaskan oleh variabel lain di luar model penelitian.

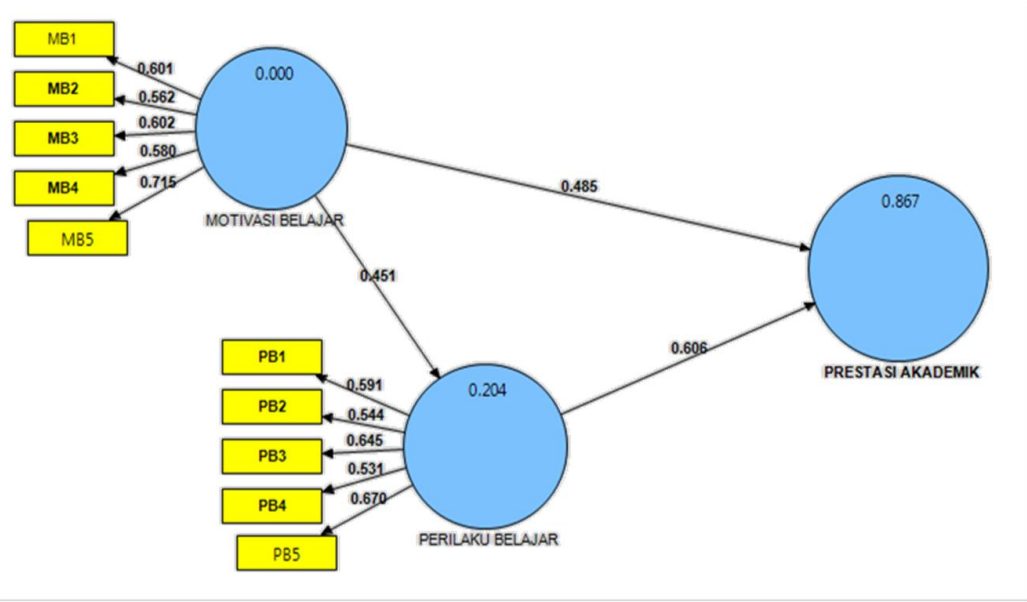

Gambar 1 Model Struktural Prestasi Akademik, Motivasi dan Perilaku Belajar

Selain dengan menggunakan $R$-square, goodness of fit model juga diukur dengan menggunakan QSquare predictive relevance untuk model struktural, mengukur seberapa baik nilai observasi dihasilkan oleh model dan juga estimasi parameternya. Nilai Q-square > 0 menunjukkan model memiliki predictive relevance; sebaliknya jika nilai $Q$-Square $\leq 0$ menunjukkan model kurang memiliki predictive relevance.

Berdasarkan tabel 8, dapat dinyatakan bahwa seluruh variabel memiliki relevansi prediksi yang baik terbukti dari nilai Q-Square yang melebihi angka 0 (nol).

Tabel 8 Nilai Q-Square Variabel Penelitian

\begin{tabular}{lccc}
\hline \multicolumn{1}{c}{ Variabel } & SSO & SSE & Q-Square (1-SSE/SSO) \\
\hline Motivasi Belajar & 750.000000 & 465.488762 & 0.379348 \\
Perilaku Belajar & 750.000000 & 470.770965 & 0.372305 \\
Prestasi Akademik & 150.000000 & 0.96462200 & 0.993569 \\
\hline
\end{tabular}

Sumber: Data Primer Diolah

3. Pengujian Hipotesis. Signifikansi parameter yang diestimasi memberikan informasi yang sangat berguna mengenai hubungan antara variabel-variabel penelitian. Dasar yang digunakan dalam menguji hipotesis adalah nilai yang terdapat pada output result for inner weight. Tabel 9 memberikan output estimasi untuk pengujian model struktural.

Tabel 9 Nilai Hasil Uji Bootstrap Koefisien Jalur Konstruk Penelitian

\begin{tabular}{lccccc}
\hline \multicolumn{1}{c}{ Konstruk } & $\begin{array}{c}\text { Original } \\
\text { Sample (O) }\end{array}$ & $\begin{array}{c}\text { Sample } \\
\text { Mean (M) }\end{array}$ & $\begin{array}{c}\text { Standard Deviation } \\
\text { (STDEV) }\end{array}$ & $\begin{array}{c}\text { Standard Error } \\
\text { (STERR) }\end{array}$ & $\begin{array}{c}\text { T Statistics } \\
(|\mathrm{O} / \mathrm{STERR}|)\end{array}$ \\
\hline Motivasi Belajar & 0.451466 & 0.480295 & 0.094507 & 0.094507 & 4.777060 \\
Perilaku Belajar & 0.757971 & 0.765626 & 0.043208 & 0.043208 & 17.542440 \\
Prestasi Akademi & 0.605730 & 0.603070 & 0.053456 & 0.053456 & 11.331441 \\
\hline
\end{tabular}

Sumber: Data Primer Diolah

Pengujian Hipotesis 1 : Pengaruh Motivasi Terhadap Prestasi Akademik

Hipotesis 1 menyatakan bahwa Motivasi berpengaruh positif dan signifikan terhadap Prestasi Akademik. Hasil uji terhadap koefisien parameter antara Motivasi terhadap Prestasi Akademik menunjukkan adanya pengaruh yang positif dengan nilai koefisien sebesar 0.452 dengan nilai t-statistik sebesar 4.777 dan signifikan pada $a=0.05$. Nilai t-statistik tersebut berada di atas nilai kritis 1.96 , dengan demikian $\mathrm{H} 1$ diterima. 
Persamaan yang dapat dibentuk untuk menggambarkan keterkaitan dua variabel tersebut adalah sebagai berikut : Prestasi Akademik = 0,452 Motivasi Belajar + 0.095

Pengujian Hipotesis 2 : Pengaruh Motivasi Terhadap Perilaku Belajar

Hipotesis 2 menyatakan bahwa Motivasi berpengaruh positif dan signifikan terhadap Perilaku Belajar. Hasil uji terhadap koefisien parameter antara motivasi terhadap perilaku belajar menunjukkan adanya pengaruh yang positif dengan nilai koefisien sebesar 0.758 dengan nilai t-statistik sebesar 17.542 dan signifikan pada $a=0.05$. Nilai t-statistik tersebut berada pada di atas nilai kritis 1.96 , dengan demikian $\mathrm{H} 2$ diterima. Persamaan yang dapat dibentuk untuk menggambarkan keterkaitan variabel Motivasi dan Perilaku Belajar tersebut adalah sebagai berikut : Perilaku Belajar $=0,757$ Motivasi Belajar +0.043

Pengujian Hipotesis 3 : Pengaruh Perilaku Belajar Terhadap Prestasi Akademik

Hipotesis 3 menyatakan bahwa Perilaku Belajar berpengaruh positif dan signifikan terhadap Prestasi Akademik. Hasil uji terhadap koefisien parameter antara Perilaku Belajar terhadap Prestasi Akademik menunjukkan adanya pengaruh yang positif dengan nilai koefisien sebesar 0.606 dengan nilai t-statistik sebesar 11.331 dan signifikan pada $\alpha=0.05$. Nilai t-statistik tersebut berada pada di atas nilai kritis 1.96 , dengan demikian H3 diterima. Persamaan yang dapat dibentuk untuk menggambarkan keterkaitan variabel Perilaku Belajar dan Prestasi Akademik tersebut adalah sebagai berikut : Prestasi Akademik = 0,606 Perilaku Belajar + 0.053

\section{Pembahasan}

\section{Pengaruh Motivasi terhadap Prestasi Akademik}

Hasil analisis data menunjukan bahwa Motivasi berpengaruh positif dan signifikan terhadap Prestasi Akademik Mahasiswa STIE Kesatuan Bogor. Hal ini memiliki makna bahwa lima indikator dalam variabel motivasi yaitu: target yang ingin dicapai (MB1), kuliah sangat penting untuk bekal di masa depan (MB2), adanya penghargaan yang sesuai (MB3), adanya persaingan (MB4) dan Proses perkuliahan yang menyenangkan (MB5) memiliki pengaruh yang positif dan signifikan dalam meningkatkan Prestasi Akademik Mahasiswa STIE Kesatuan Bogor. Semakin baik motivasi para mahasiswa maka akan semakin baik Prestasi Akademiknya. Dengan kata lain, untuk meningkatkan Prestasi Akademik para Mahasiswa dapat dilakukan berbagai upaya peningkatan kesadaran akan target yang ingin dicapai, kesadaran bahwa kuliah sangat penting untuk bekal di masa depan, kesadaran akan adanya persaingan. Termasuk adanya upaya pihak eksternal (keluarga, Masyarakat dan Sivitas Akademika) untuk memberikan penghargaan yang sesuai serta menghadirkan Proses perkuliahan yang menyenangkan bagi para mahasiswa.

Hasil penelitian ini sejalan dengan penelitian yang dilakukan antara lain :

a. Metriana (2014) yang dalam Hasil penelitiannya menunjukkan bahwa motivasi, perilaku belajar dan self-efficacy berpengaruh secara positif dan signifikan terhadap prestasi akademik.

b. Tjahjaning Poerwati (2009) yang menyimpulkan bahwa motivasi berpengaruh terhadap prestasi akademik.

c. Rizkhi Ika Purnama Sari (2013) yang menunjukkan adanya pengaruh positif dan signifikan antara proses belajar mengajar, motivasi belajar dan lingkungan belajar terhadap prestasi belajar.

Dengan demikian dapat dikatakan bahwa Motivasi Belajar menjadi penting ditingkatkan, ketika terdapat upaya untuk meningkatkan Prestasi Akademik para mahasiswa.

\section{Pengaruh Motivasi terhadap Perilaku Belajar}

Hasil analisis data pun menunjukan bahwa kelima indikator Motivasi mempengaruhi secara positif dan signifkan variabel Perilaku Belajar Mahasiswa STIE Kesatuan Bogor. Kelima indikator tersebut terbukti kuat mempengaruhi lima indikator Perilaku Belajar Mahasiswa yang terdiri dari Perilaku belajar di rumah atau kos (PB1), Perilaku membaca buku (PB2), Perilaku saat menghadapi ujian (PB3), Perilaku mengunjungi perpustakaan (PB4) dan Perilaku mengikuti perkuliahan (PB5). Kelima perilaku tersebut akan meningkat seiring dengan adanya peningkatan Motivasi Belajar mahasiswa. Hasil penelitian ini sejalan dengan penelitian yang dilakukan antara lain: Jeanne Ellis Ormrod (2010) dalam bukunya yang berjudul Educational Psychology, menjelaskan berbagai pengaruh motivasi terhadap perilaku dan proses belajar siswa 


\section{Pengaruh Perilaku Belajar Terhadap Prestasi Akademik}

Berdasarkan hasil analisis data, Prestasi Akademik dapat ditingkatkan melalui peningkatan Perilaku Belajar. Hal ini terbukti adanya pengaruh secara positif dan signifikan antara variabel Perilaku Belajar dan Prestasi Akademik Mahasiswa STIE Kesatuan Bogor. Kelima indikator Perilaku Belajar Mahasiswa yang terdiri dari Perilaku belajar di rumah atau kos (PB1), Perilaku membaca buku (PB2), Perilaku saat menghadapi ujian (PB3), Perilaku mengunjungi perpustakaan (PB4) dan Perilaku mengikuti perkuliahan (PB5) harus ditingkatkan jika mengharapkan adanya peningkatan Prestasi Akademik Mahasiswa. Hasil penelitian ini sejalan dengan penelitian yang dilakukan antara lain:

a. Hanifah (2001) yang membuktikan bahwa Perilaku belajar berpengaruh positif dan signifikan terhadap prestasi akademik.

b. Golemen (2002:273) yang menyatakan bahwa mayoritas mahasiwa yang mempunya prestasi buruk mereka tidak memiliki satu atau lebih unsur kecerdasan emosional tanpa harus melihat sejauh mana mahasiswa mempunyai kesulitan dan ketidakmampuan dalam belajar.

Penutup

Simpulan

Beberapa simpulan penelitian ini adalah sebagai berikut :

a. Motivasi Belajar berpengaruhi positif dan signifikan terhadap Prestasi Akademik. Hal ini menunjukkan bahwa peningkatan Prestasi Akademik dapat dicapai melalui peningkatan Motivasi Belajar Mahasiswa STIE Kesatuan Bogor. Motivasi Belajar yang semakin baik dan meningkat akan meningkatkan Prestasi Akademik para Mahasiswa.

b. Motivasi Belajar berpengaruh positif dan signifikan terhadap Perilaku Belajar. Hal ini menunjukkan bahwa peningkatan Perilaku Belajar dapat diraih melalui peningkatan Motivasi Belajar Mahasiswa STIE Kesatuan.

c. Perilaku Belajar berpengaruh positif dan signifikan terhadap Prestasi Akademik. Hal ini menunjukkan bahwa Perilaku Belajar yang semakin baik dan meningkat akan meningkatkan Prestasi Akademik Mahasiswa.

Implikasi Manajerial

a. Peningkatan Prestasi Akademik para Mahasiswa dapat dilakukan melalui berbagai upaya peningkatan kesadaran akan target yang ingin dicapai, kesadaran bahwa kuliah sangat penting untuk bekal di masa depan, kesadaran akan adanya persaingan. Termasuk adanya upaya pihak eksternal (keluarga, Masyarakat dan Sivitas Akademika) untuk memberikan penghargaan yang sesuai serta menghadirkan Proses perkuliahan yang menyenangkan bagi para mahasiswa.

b. Perilaku belajar di rumah atau kos (PB1), Perilaku membaca buku (PB2), Perilaku saat menghadapi ujian (PB3), Perilaku mengunjungi perpustakaan (PB4) dan Perilaku mengikuti perkuliahan (PB5) harus ditingkatkan jika mengharapkan adanya peningkatan Prestasi Akademik Mahasiswa.

\section{Daftar Pustaka}

Cooper., Donald R. and chindler., Pamela S. 2003. Business Research Methods. Boston: International edition. Mc Graw Hill

Davis, Keith \& John W.Newstrom, (1987). Perilaku Dalam Organisasi. Jilid 1 Edisi 2. Alih bahasa Agus Dharma. Jakarta: Erlangga.

Ghozali, I., 2008. Structural Equation Modeling : Metode Alternatif Dengan Partial Least Square. Badan Penerbit Universitas Diponegoro, Semarang.

Gilles, E. Gignac, Benjamin R. Palmer. 2010. The Genos employee motivation assessment. Emerald Group Publishing Limited, ISSN 0019-7858 Genos, Waterloo, Australia Vol. 43 No 2. pp.. 79-87

Goleman, Daniel. 2002.Working With Emotional Intelligence (terjemahan). PT.Gramedia Pustaka Utama. Jakarta..

Goleman, D. 2002. Emotional intellengence : kecerdasan emosional, mengapa EL lebih penting dari pada IQ. Jakarta: PT gramedia pustaka utama

Gomes, Faustino Cardoso. 2003. Manajemen Sumber Daya Manusia, Bandung: Remaja Rosdakarya 
Gorda, IGN. 2004. Manajemen Sumber Daya Manusia.Cetakan ke-2. ASTABRATA Bali Denpasar bekerja sama dengan STIE Satya Dharma Singaraja

Hanifah, Syukriy Abdullah(2001), Pengaruh Perilaku Belajar Terhadap Prestasi Akademik MahasiswaAkuntansi, Media Riset Akuntansi, Auditing dan Informasi, Vol 1 No 3 Desember 2001.

Majid, Abdul. (2005). Perencanaan Pembelajaran: Mengembangkan Standar Kompetensi Guru. Bandung: Remaja Rosdakarya.

Mulyasa, E., (2003). Kurikulum Berbasis Kompetensi: Konsep, Karakteristik, dan Implementasi. Bandung: PT Remaja Rosdakarya.

Omrod, Jeanne Ellis, 2010. Educational Psychology: Developing Learners (7th Edition). Pearson.

Rivai, Veithzal, (2003), Kepemimpinan dan Perilaku Organisasi. Jakarta: Rajagrafindo Persada. Ed-2.

Robbins, Stephen P, (2008), Perilaku Organisasi. Ed.2 Alih bahasa Dianan Angelica. Jakarta: Salemba Empat.

Robotham, David, (1996), Competences : Measuring The Immeasurable, Management Development Review, Vol. 9, No. 5, hal. 25-29

Ruky, Ahmad S. (200). Sistem Manajemen Kinerja. Jakarta: Gramedia.

Rusman, (2011). Manajemen Kurikulum. Cet.3. Jakarta: RajaGrafindo Persada.

Sarmiento, Roberto and Jo Beale, (2007). Determinants of performance amongst shop-floor employees: a preliminary investigation, Management Research News, Vol.30 No.12.

Sizoo, Steve, Richard Plank, William Paterson, Wayne, Wilfried, Iskat Rosen, and Hendrick Serrie Eckerd. 2005. Journal of Services Marketing. 19/4 (2005) 245-255. q Emerald Group Publishing Limited.

Veithzal Rivai \& Ahmad Fawzi Mohd Basri. 2005. Performance Appraisal Sistem Yang Tepat Untuk Menilai Kinerja Karyawan Dan Meningkatkan Daya Saing Perusahaan.. PT. Raja Grafindo Persada, Jakarta.

Weinrauch, J. Donald; O. Karl Mann; Patricia A Robinson; \& Julia Pharr , 1991. Dealing with Limited Financial Resources: A Marketing Challenge for Small Business. Journal of Small Business Management; 29, 4; pg. 4

Widodo Joko, 2005. Membangun Birokrasi Berbasis Kinerja, Bayumedia Publishing, Malang 